\title{
BRITISH CONSULAR REPORTS ON THE TRADE AND POLITICS OF LATIN AMERICA, 1824-1826
}




\section{BRITISH CONSULAR REPORTS ON THE TRADE AND POLITICS OF LATIN AMERICA 1824-1826}

EDITED FOR THE ROYAL HISTORICAL SOCIETY

BY

R. A. HUMPHREYS

M.A., PH.D., F.R.Hrst.S.

CAMDEN THIRD SERIES

VOLUME LXIII

LONDON

OFFICES OF THE ROYAL HISTORICAL SOCIETY 96 CHEYNE WALK, S.W.10

1940 
Printed in Great Britain by Butler \& Tanner Ltd., Frome and London 


\section{CONTENTS}

PAGE

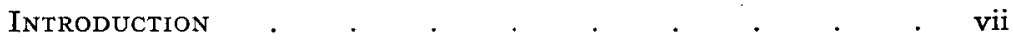

List of Documents . . . . . . . . . . $\quad$ xv

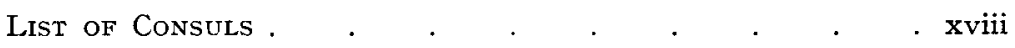

GLOSSARY . . . . . . . . . . . . $\quad$. .

Currency, Weights, and Measures . . . . . . $\quad$ xxi

List of AbBreviations . . . . . . . . . . xxii

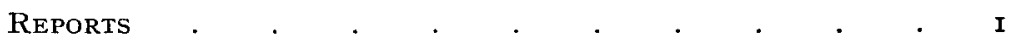

APPENDIX I :

A. Exports in Pounds Sterling of British and Irish

Goods From Great Britain to Latin America, I8I2-I830

B. Exports in Pounds Sterling of Foreign and Colonial Merchandise from Great Britain to Latin America,

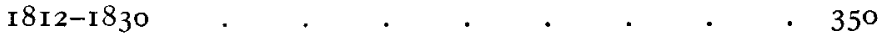

Appendix II: Note on Spanish Commercial Reforms in the

Eighteenth Century . . . . . . 352

APPENDIX III :

A. List OF Manuscripts cited . . . . . . $\quad$. 354

B. List of References . . . . . . . . . 354

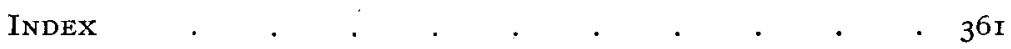

Map of Latin America IN I826. . . . . . . at end 